\title{
Arquitectura religiosa en los Andes: apogeo, crisis y restauración
}

Recibido: 01/09/2016

Aprobado: 10/10/2016

\author{
Román Robles Mendoza \\ Universidad Nacional Mayor de San Marcos \\ $<$ hermanovallejo@hotmail.com >
}

\begin{abstract}
RESUMEN
Desde la llegada de los españoles a tierras del Tahuantinsuyo se edificaron magníficas iglesias como parte del proceso de cristianización de los vencidos. La iglesia se constituyó en espacio propicio para la expresión de artes como la arquitectura, la escultura y la pintura, venidas de Europa renacentista, que se enriqueció aún más con la fusión del arte indígena y mestizo. En las ciudades mayores florecieron las catedrales y los conventos, fundados por las distintas órdenes religiosas; mientras que en las localidades menores, como en las reducciones de indios, la iglesia fue erigida como el edificio principal, ubicada en la plaza, con sus altos campanarios para llamar a los conversos. En cerca de cinco siglos de historia, las numerosas iglesias construidas en el Perú han tenido su época de esplendor y apogeo, así como su decaimiento y crisis. Estos repositorios del arte colonial, vinculadas a la propagación del cristianismo, se encuentran en la actualidad; unos en buen estado de conservación y activos, otros se han deteriorado con el paso del tiempo, calamidades telúricas y desuso prolongado. En este artículo hacemos un examen etnográfico de estos monumentos históricos, enfatizando principalmente el proceso de remodelación de la arquitectura y del arte religioso colonial, que tienen por objeto ponerlo en valor e incentivar la neoevangelización moderna.
\end{abstract}

Palabras clave: cristianización, iglesias andinas, arte religioso, restauración de iglesia, neoevangelización.

\section{Religious architecture in the Andes. Apogee, crisis and restoration}

\begin{abstract}
Since the arrival of the Spaniards to the Tahuantinsuyo land magnificent churches as part of the process of Christianization of the vanquished they were built. The church was established in propitious space for the expression of arts such as architecture, sculpture and painting, coming from Renaissance Europe, which is enriched with the fusion of Indian and mestizo art. In big cities they flourished cathedrals and monasteries, founded by different religious orders; while in smaller towns, such as reductions of Indians, the church was built as the main building, located in the square, with its high bells to call converts. In about five centuries of history, numerous churches built in Peru have had their time of splendor and apogee as well as their decline and crisis. These repositories of colonial art linked to the spread of Christianity are at present; some in good condition and assets, others have deteriorated over time, telluric calamities and prolonged disuse. This article presents an ethnographic examination of these historical monuments, mainly emphasizing the process of remodeling colonial architecture and religious art, which aims to put in value and encourage modern Neoevangelization.
\end{abstract}

KeYwords: Christianization, Andean Churches, Religious art, Church Restoration, Neoevangelization. 


\section{Introducción}

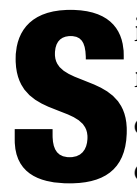
in la menor duda, el símbolo material más representativo de la expansión religiosa cristiana en esta parte de América ha sido y es la iglesia. En estos colosales edificios están resumidos los diversos recursos metodológicos del proceso de catequización, que los colonizadores peninsulares emplearon en uno de sus objetivos primordiales de dominación: la cristianización. La iglesia ${ }^{1}$ fue desde sus orígenes un espacio dedicado al culto religioso y un repositorio de imágenes escultóricas y pictóricas de los símbolos de la cristiandad. Fue también y sigue siendo, el centro de la predicación del evangelio, mediante la oratoria y el sermón, de la música y del canto sacro, así como de toda forma de escenificación teatralizada de ritos y ceremonias religiosas, implantadas por la tradición cristiana en el mundo europeo, que se trasladaron a la América conquistada, con el mismo fervor y la pompa instituida por el cristianismo desde Roma, centro fundamental de la propagación de la nueva religión nacida en Israel.

A lo largo y ancho de las colonias implantadas por los espańoles y portugueses en el continente sudamericano, edificaron sendas iglesias. En cada ciudad fundada por los aventureros espańoles, fueron construyendo iglesias, dedicadas a cada una de los muchos santos y santas del santoral cristiano. En las principales ciudades como Lima, Cusco, Arequipa, Huamanga ${ }^{2}$, Cajamarca, Piura, edificaron varias iglesias locales, de acuerdo a la presencia de las órdenes religiosas que llegaron de Europa, con el expreso objetivo de evangelizar a las sociedades vencidas. En las poblaciones menores y en las reducciones de indios, el edificio principal de estos nuevos asentamientos poblacionales era evidentemente la iglesia. En la mayoría de las poblaciones fundadas por los espańoles, la iglesia estaba situada en la plaza. Edificio de gran tamaño, con espaciosas naves, lo suficientemente amplios para albergar a la población del entorno. La mayoría de ellas, fueron dotadas de un órgano de fuelle, situado en el altillo de la entrada al templo, dos campanarios situados a los costados; en otros casos, fuera del cuerpo de la iglesia, en un promontorio o en un lugar abierto, para llamar a los conversos me-

1 El concepto de iglesia es tomado en este trabajo, no en referencia institucional, sino en su acepción de arquitectura religiosa, como sinónimo de templo. Al referirnos a la institución lo haremos con la I inicial con mayúscula.

2 En la ciudad de Huamanga se edificaron 33 iglesias que siguen activas hasta nuestros días. diante las campanadas de estilo. El espacio circundante a la iglesia del pueblo estaba reservado para el cementerio, lugar donde los conversos debían enterrar a sus muertos, en sustitución de hacerlo en las cuevas más cercanas a los ayllus. Por esta razón, hasta estos tiempos, el edificio principal y visible de las poblaciones del interior del país siguen siendo las iglesias y sus altas torres techadas a dos aguas. En varios lugares, las vibraciones de las campanas se escuchan a muchos kilómetros a la redonda. A las campanas grandes y sonoras, como la del Cusco o la de Mangas, se les llama hasta ahora, la "María Angola".

Durante el primer siglo de dominación colonial se edificaron las más antiguas iglesias cristianas. En los siglos siguientes, XVII y XVIII, se construyeron iglesias en todas las poblaciones de la Colonia del Perú. En casi cinco siglos de historia, las iglesias coloniales han tenido distintas trayectorias. Tuvieron su época de esplendor hasta el siglo XIX. Luego, han sufrido deterioros, tanto por los efectos de movimientos sísmicos como por su vejez y falta de mantenimiento. Hasta la actualidad, las iglesias situadas en las grandes poblaciones se encuentran mejor conservadas, tanto por su constante actividad como por su especial cuidado y su puntual refacción de paredes, techos, hornacinas, pisos, puertas y ventanas. (San Cristóbal 2004; Robles 2005: Tord 1983). En las localidades menores, las iglesias han sufrido mayores deterioros en sus estructuras y en su conservación interna y externa. En todas partes, los fenómenos telúricos han resquebrajado cimientos, paredes y techos. Reconstruirlos ha sido y es una tarea difícil y costosa, situación que los mantiene en mal estado y también en abandono, algunas de ellas en escombros. El abandono y escasa actividad religiosa pone también su cuota. En distintas regiones del país, algunas iglesias ya no tienen uso, por ausencia de sacerdotes y por la escasa actividad religiosa de la población. En general, la mayoría de las iglesias de los pueblos del interior se encuentran operativas en mayor o menor grado. La continuidad de la actividad religiosa ayuda a que las iglesias mantengan su buen estado de conservación.

Desde la fundación colonial de las reducciones, los nuevos asentamientos poblacionales indígenas $\mathrm{y}$, por tanto sus iglesias, fueron bautizados con el nombre de algún ícono del cristianismo. Por esta política religiosa de los colonizadores, la imagen principal de cada iglesia edificada ha sido un santo o una santa, con cuyo nombre fue fundada también cada población. De este modo, aparecen nombres de pueblos con la advoca- 
ción del santoral designado, tales como: San Miguel de Piura, Virgen de las Mercedes de Carhuaz, Santo Domingo de Huasta, Virgen de Rosario de Huari, San Agustín de Cajacay, Santa Catalina de Pimachi, San Bartolomé de Pacllón, Virgen de la Natividad de Cocharcas, Santiago de Corongo, Virgen del Carmen de Paucartambo, etc, etc. Pero los catequizadores coloniales no se quedaron satisfechos con un solo santo patrón o patrona en cada localidad, dotaron de varios santos y santas a todas las iglesias. La edificación del altar mayor, muy bien dispuesto con la imagen del crucificado, del patrono local y de varios otros santos ubicados en sendas hornacinas, muy bien labradas, se vio acompańado de varios retablos de madera enlucidos en pan de oro, en ambos lados de la nave, igualmente con imágenes de más santos y santas de canonización europea. Un ejemplo es la iglesia de Chivay en Arequipa, que cuenta con 31 imágenes escultóricas. Con el tiempo se agregarían también santos y santas de origen americano. A esta pléyade de imágenes se sumaron Santa Rosa de Lima, San Martín de Porras, Virgen de Copacabana (Bolivia), virgen de Guadalupe para el caso mexicano, para citar algunos. Asimismo, en todas las iglesias, sin excepción, se colocaron varias imágenes de Cristo, en distintas situaciones. Inducir la cristianización en la mente de los naturales del nuevo mundo, supuso esculpir a Cristo en una vasta cantidad de imágenes, que mostraran, la vida, pasión, muerte y resurrección del fundador de esta religión. Por la misma razón, explicar la nueva fe en la conciencia de los vencidos, significó hacer la representación teatral del martirologio del nazareno $^{3}$, obligatoriamente, una vez al ańo, durante las ceremonias de la Semana Santa. De esta suerte, la santa o el santo patronal de cada localidad y la Semana Santa, se constituyeron en dos rituales y fiestas obligatorias de cada pueblo. Sobre estas dos efemérides se agregaron otras festividades cristianas, cuyos costos de financiamiento pesaban y siguen pesando sobre los hombros de la población colonizada.

Durante toda la etapa colonial, las iglesias tuvieron su explicable apogeo. Se usaron varios modelos arquitectónicos, desde edificios sencillos hasta modelos complejos, a imitación de las iglesias europeas, como lo demuestran las iglesias de Copacabana o las de Juli, Pomata y Lampa en Puno. La estructura sólida del edificio ha sido la característica principal, edificada con

3 Las ceremonias de la Semana Santa en el Perú son pan andinas. En casi todas las poblaciones se escenifican las estaciones y la desclavación de Cristo. Ayacucho es la localidad más ostentosa en estos rituales. hileras de adobes de hasta un metro y medio de espesor en las paredes principales y en algunos casos se usaron ladrillos adosados en cal y canto. La mayoría de las iglesias de los pueblos del interior se techaron con paja renovable, pero en las ciudades y poblaciones importantes, los techos se hicieron de tejas labradas o de lajas de piedra y ladrillos pegados con cal y canto. En casi todas las iglesias se agregaron los altillos para el coro y para la ubicación del órgano a fuelle, que en Europa renacentista se constituyó en el principal instrumento musical para acompañar los fastuosos rituales sacros de las grandes catedrales. El cielo raso y las paredes laterales de las iglesias recibieron tratamiento especial, con pinturas del firmamento hacia arriba y con dibujos de una diversidad de motivos, principalmente religiosos, en sus paredes. Las iglesias del lado sur del Perú, desde Ayacucho hasta Puno y Bolivia, se beneficiaron con obras del arte pictórico, hechos en lienzos, para ser colgados en las paredes laterales de estos edificios sagrados (Compañía de Jesús 2015; Campos Vera 2012; San Cristóbal 2004). Son muchas las iglesias que hasta hoy atesoran hermosos cuadros de la conocida Escuela Cusqueña. La de Paucartambo en Cusco, es una buena muestra de la belleza del arte pictórico colonial en un medio rural. Por todo esto, las iglesias coloniales recibieron las mejores atenciones para su embellecimiento. Esmerado arte arquitectónico, exquisita iconografía, expresada en esculturas de Cristos, santos, santas, monjes, papas, así como hermosos cuadros pintados por los mejores talentos de Europa y de América.

La República emancipada heredó una estructura administrativa religiosa muy bien organizada, con una numerosa red de iglesias debidamente implementadas, regentadas por las distintas órdenes religiosas, centralizadas en el Arzobispado de Lima. Por distintas causas, los dos siglos de vida republicana no han logrado mantener la misma organización de las iglesias dejadas por los colonizadores (Vargas Ugarte 1953-1962). Si bien el catolicismo siguió siendo la religión oficial del Estado Peruano, la administración y la dotación de párrocos en todas las localidades con iglesias, ya no recibió la misma atención que en el coloniaje. Durante el siglo XIX se vivió la continuidad colonial de la vida religiosa y también de su inevitable crisis. La institución religiosa ya no recibía el diezmo, que los españoles implementaron para el mantenimiento de cada parroquia y el sostenimiento de los sacerdotes. Con el tiempo, los bienes raíces (tierras agrícolas, solares y mano de obra gratuita) dedicados a los santos, también instituidos 
durante la colonia, pasaron lentamente al dominio de las comunidades indígenas. Sin embargo, han sido y siguen siendo en varias regiones, los mismos comuneros los que han atendido y atienden el mantenimiento permanente de las iglesias, mediante las faenas comunales. Para estos fines, los españoles traspasaron estas responsabilidades al sistema de autoridades de vara de cada localidad, que todavía se mantienen en algunos lugares 4 . Con mayor énfasis desde el siglo XX, las parroquias de las provincias del interior, han ido disminuyendo en el número de sacerdotes para atender a toda la feligresía. En la actualidad, continúa esta crisis, cuando los distritos parroquiales tienen uno o dos sacerdotes para atender a veinte o treinta poblaciones de su entorno. Por esta escasez de profesionales, algunas localidades no son atendidas en sus requerimientos. Estas y otras causas han determinado la crisis y el decaimiento de muchas iglesias del interior del país. Algunas de ellas se han deteriorado por completo, también se desmoronaron con sismos y terremotos. Otras iglesias han sido reconstruidas en largos periodos de tiempo, hay algunas que no han vuelto a levantarse. Muchas artes coloniales se han perdido con el deterioro, la destrucción y el robo sacrílego de estos cofres arquitectónicos del arte colonial.

En los últimos tiempos, se observa un proceso de reconstrucción de estos monumentos históricos, refacción y rescate de las iglesias en mal estado de conservación. El interés por volverlos a poner en valor, viene por distintas instituciones religiosas y laicas, nacionales y extranjeras. En muchos casos, son los municipios locales y provinciales y las comunidades campesinas, los que hacen esfuerzos por reconstruir las iglesias, por considerar que forman parte del patrimonio cultural y la simbología del pensamiento religioso adoptado. Otros casos de reconstrucción y remodelación, se vienen haciendo a través de convenios con gobiernos e instituciones religiosas del extranjero. No menos importante es el papel que la Compañía de Jesús (Jesuitas) ha asumido en los últimos años, el papel de restituir la prestancia de las antiguas iglesias de Cusco rural's, que esta orden religiosa mandó construir y equipar durante su permanencia en América de la fase colonial, antes de ser expulsados de América en 1769. Vienen haciendo

$4 \quad$ Las autoridades de vara se encargan en la mayoría de casos, a cuidar el orden y hacer cumplir las obligaciones instituidas a los responsables de organizar la celebración de la Semana Santa.

5 La restauración de las iglesias de Andahuaylillas y de Huaro son los mejores ejemplos en el Cusco rural. un trabajo encomiable, especialmente en las iglesias de la provincia de Quispicanchi, conocidas por su impresionante belleza del arte barroco de sus interiores, donde la pintura, la escultura y el tallado en madera forman parte del tesoro artístico dejado por los jesuitas de los siglos XVI al XVIII (La compañía de Jesús 2015)..

\section{Colonización socioeconómica y colonización mental}

Para la corona española, revitalizada por la expulsión del último reducto de la dominación morisca en la península, el descubrimiento y la conquista del nuevo continente, significó la ampliación de sus dominios y la multiplicación de sus riquezas. La conquista de los aztecas, chibchas y los incas, a sangre y fuego, fue la culminación de los esfuerzos de los reinos de Castilla y Aragón, depositados en el proyecto de Cristóbal Colón, de abrir nuevas rutas hacia las riquezas de oriente a través de la navegación por el oeste del mar Atlántico. Se embarcaron en las carabelas y galeones, guerreros bien armados de arcabuces, mosquetes, espadas de hierro, armaduras forjadas y caballos. También se embarcaron sacerdotes, primero como soldados y aventureros, luego organizados en distintas órdenes religiosas que se formaron en la península desde el siglo XIII. A este proceso, han denominado los historiadores, como la "conquista de la espada y la cruz" de los pueblos de América. Lo que hizo España en estas tierras conquistadas fue organizar el sistema colonial, asegurándose del control de las riquezas naturales, de la mano de obra indígena y de la recaudación de tributos a favor del rey de España, de los encomenderos y el clero. Ellos tenían una larga experiencia en artes de la dominación de pueblos y culturas, por haberla vivido por siglos, entre conquistas y liberaciones. El sistema colonial impuesto por los vencedores acabó casi de inmediato con toda la grandeza económica, social y cultural de la sociedad andina.

Conquistar el imperio de los Incas, en plena guerra civil, entre los herederos de Huayna Cápac: Huáscar y Atahualpa, fue relativamente fácil, a diferencia de la conquista de los aztecas que se prolongó por más de dos años de resistencia. Aproximadamente doscientos hombres, dirigidos por Francisco Pizarro, dotados de armas de fuego y montados a caballo, irrumpieron en Cajamarca, provocando pánico y muerte, apresando allí al último Inca en ejercicio del poder del imperio más 
extenso de América del Sur. La espada y el arcabuz se impusieron en una contienda que enfrentó a miles de soldados quechuas armados de porras, flechas y hondas. Con esta inmensa población vencida, de más de diez millones de habitantes, organizaron la Colonia de Perú, a partir de los escombros de la guerra de conquista. Desde entones, el Tahuantinsuyo sufrió el latrocinio del estado, la rapińa de los templos, cuando no el etnocidio sobre los vencidos. La dominación colonial no hizo distingo de rangos del sistema sociopolítico quechua, incluyó a los administradores de suyos (Las cuatro regiones), de hunus (Grupos de 10,000), de warancas (Grupos de 1,000), de pachacas (Grupos de 100); igual trato recibieron los sacerdotes, los técnicos, los ingenieros, los astrónomos, los contadores y estadígrafos (Quipucamayoc) y el hatun runa del gran imperio. Con la contundencia de la espada y el arcabuz, los españoles sometieron en poco tiempo, a un pueblo que había construido una poderosa nación, políticamente bien organizada y económicamente productiva, "sin copia ni calco" de otras sociedades: de creación auténticamente americana. Se apoderaron de sus riquezas, de sus tierras, de sus minas y de la inmensa fuerza de trabajo. La economía agrícolaganadera prehispánica devino en una economía preferentemente extractiva, que aportó con abundante cargamento de oro y plata a la metrópoli, en plena expansión colonizadora intercontinental.

Con el símbolo de la cruz, completaron el proceso de dominación colonial del Perú antiguo. Junto con los líderes de la conquista y de los soldados españoles, llegaron también los sacerdotes, representantes de la religión cristiana, que ya se había afirmado en la península, en más de mil quinientos años de expansión del evangelio de Cristo. Los religiosos llegaron organizados en varias órdenes, tales como: la Orden fundada por Santo Domingo de Guzmán (dominicos), la Orden establecida por San Francisco de Asis (Franciscanos), la Orden de Nuestra Señora de la Merced (Mercedarios), la Orden de San Agustín (Agustinos), la Orden de la Compañía de Jesús (Jesuitas) fundada por Ignacio de Loyola, entre otros. Fueron estos grupos de religiosos, los que se encargaron del trabajo de la catequización de los pueblos vencidos, como lo señalan Mariano Cuevas (1947) para el Virreinato de Nueva España (México) y Rubén Vargas Ugarte (1953-1962) para el Virreinato del Perú. El envío de sacerdotes para la catequización, fue una empresa directamente encomendada por los reyes católicos de España y por el Papado de Roma, en estricto acatamiento de las disposiciones adoptadas en el Concilio ecuménico de Trento. Para tal efecto, la jerarquía eclesiástica instalada en Lima, para el caso del Perú, hizo una distribución territorial, que los Concilios Limenses ${ }^{6}$ se encargarían de precisarlas y de dictar normas y estrategias para la evangelización de los indígenas. Con los mismos fines, en el Virreinato de Nueva Espańa, se realizaron igualmente concilios, aunque en menor número y precisiones que los del Perú. Don Bernardino de Sahagún (1975 y 1986), uno de los más insignes cronistas de México, describe en sus obras escritas en lengua náhuatl, el proceso de evangelización de los aztecas, vencidos finalmente por Hernán Cortés y sus huestes en 1521; a su vez, Duverger (1996) ha sintetizado este proceso en su versión moderna, enfatizando el adelantado papel que cumplieron los doce frailes franciscanos, enviados en 1524 por el Papa Adriano VI y el emperador Carlos V, detallados en los Coloquios de Bernardino de Sahagún (1582). Los artífices de los cónclaves de obispos o Concilios Limenses fueron los primeros arzobispos de la sede Metropolitana de Lima: Gerónimo de Loayza (Concilios I y II) y Santo Toribio de Mogrovejo (Concilios III, IV y V); este último, incansable viajero de visitas pastorales por el territorio andino. Toda la política de la cristianización aplicada sobre los indios se derivó de los acuerdos tomados en estos concilios.

Por la aplicación de las directivas, tanto de Roma como del Arzobispado de Lima, los doctrineros distribuidos en todo el territorio del virreinato, debían cumplir con diversas ordenanzas en sus sedes correspondientes, como parte esencial de la política colonizadora de los reyes católicos. Con la mano de obra indígena se mandaron construir iglesias en todas las poblaciones. Refiriéndose a este proceso de edificar iglesias orientadas a la propagación de la fe cristiana, en Europa y en América, S. Dianich (2013) analiza los distintos estilos y lenguajes arquitectónicos de las iglesias. Este autor, considera que, "El lenguaje de la fe, desde el verbal conceptual hasta el de las imágenes... tiene tareas y virtualidades más amplias y múltiples. Volviendo la mirada sobre todo al mundo medieval y a su arquitectura, es fácil dejarse llevar por una lectura que disuelve el leguaje arquitectónico en un lenguaje representativo" (Dianich, Op. Cit.: 72). Direccionado desde

6 Durante el siglo XVI y comienzos del XVII, en el Virreinato del Perú, se convocaron cinco concilios, conocidos como Concilios Limenses: Primer concilio (1661-1552), Segundo concilio (1567-1568), Tercer concilio (1582-1583), Cuarto concilio (1591), Quinto concilio (1601). Fueron propiamente concilios de catequización. 
Roma, en cada templo se plasmaron pinturas murales con motivos religioso cristianos y se les dotó de abundante imaginería del santoral cristiano, principalmente de esculturas dedicadas a Cristo en sus diversas fases de vida. Por sus mismos fines, las iglesias debían ser espacios visuales de lo que significaba el cristianismo, suficientemente convincentes, para sustituir la simbología mental indígena de las creencias en las deidades prehispánicas. Se les dotó también de un púlpito, de un baptisterio y de un coro. La misa oficiada por el sacerdote debía efectuarse con la solemnidad de rigor, en un ambiente místico, lleno de imágenes de Cristos y santos, coronado por el cielo estrellado del techo de la nave y el poderoso y penetrante sonido de la música sacra interpretada por el canto y el órgano. Este recinto religioso, debía servir además para administrar todos los sacramentos que exige la iglesia cristiana para los conversos (Vargas Ugarte, Op. Cit.; Robles 1978 y 2005). Desde entonces, en los altares de las iglesias, se realizan las confirmaciones, las comuniones, los matrimonios; en el baptisterio se realizan los bautizos, uno de los sacramentos más importantes del cristianismo. Es decir, todos los actos rituales que exige la conversión de nuevos creyentes hacia la fe cristiana. Tanto las directivas emanadas del Concilio tridentino como de los Loncilios Limenses, reforzaron compulsivamente la aplicación irrestricta de todos los sacramentos creados por la iglesia católica. Dino León (2009), aporta muy bien con el análisis del proceso de evangelización en la doctrina de Canta, incluyendo el tema de las rentas de los doctrineros, las visitas eclesiásticas y las de extirpación de idolatrías. Desde que fueron implementados en el siglo XVI, se siguen aplicando hasta hoy las normas dictadas por la Iglesia Católica, con poquísimas modificaciones —en la nueva versión de continuidad de sostenimiento de la fe católica-, que se incrementa con el proceso de neoevangelización moderna. Desde una mirada moderna del siglo XX, Miguel Ángel Vidal (2013), recrea el espacio físico de las iglesias limeñas, en su directa interrelación con el ritual religioso y la estructura arquitectónica, donde se realizan estos actos. Sin duda, también los artífices de la evangelización colonial, tenían muy claro, la influencia efectista del espacio sagrado, lleno de imágenes, de música, de incienso y de verbo, sobre la conciencia de los conversos; es decir, múltiples lenguajes de la fe cristiana.

La palabra o el verbo, fue el otro vehículo de la evangelización colonial sobre los indígenas. Con la finalidad de hacerse entender por los indígenas median- te el lenguaje hablado, se exigió a los sacerdotes saber expresarse en quechua y en castellano. Por esa razón, uno de los requisitos principales para concursar a una plaza de curato vacante era saber la legua quechua. La oratoria sacerdotal expresada en quechua desde los púlpitos, era otra de las estrategias coloniales de la cristianización, cuando la nave de las iglesias estaba llena de gente. Predicar sobre las enseńanzas del evangelio de Cristo o sobre los diversos pasajes de la vida y sufrimientos de los israelitas, sacadas del Antiguo Testamento, era evidentemente conmovedor. Los sacerdotes que vinieron de España y los que se formaron en los conventos de Lima y de Cusco, tenían los mejores conocimientos del arte verbal para ser aplicados en la evangelización. La oratoria y el magisterio cristiano, principalmente expresada en quechua, se utilizaron para todo el proceso de catequización a los indígenas. Sirvió para enseñarles el catecismo, también elaborado por los concilios limenses: el credo, el padre nuestro, el Ave María y otros rezos, oraciones y cánticos, que los conversos debían aprender de memoria, sobre todas las cosas. Inculcar la fe cristiana a los indígenas mediante la palabra fue el método más directo que los doctrineros aplicaron en toda la colonia. Explicar con claridad las contradicciones entre el bien y el mal, entre los objetivos que tienen dios y el diablo, para salvar o condenar las almas humanas, se convirtió en un objetivo primordial en el proceso de catequización. Enfatizaron la idea de la salvación del alma hacia la vida eterna, cumpliendo con los mandamientos dictados por dios y no cayendo en pecado, en un mundo donde la vida está llena de acciones pecaminosas, que se deben evitar. Las órdenes religiosas se empeñaron con entera convicción para ofrecer la gloria de dios a los que aceptaban y se asimilaban a la fe cristiana y no vivan en pecado, así como explicarles que, a los no cristianos y pecadores, les espera en la otra vida, el abominable infierno gobernado por el diablo, representante del mal. Por todo esto, convertir a los infieles al cristianismo, fue una tarea difícil y complicada. Significó un denodado esfuerzo colectivo de la Colonia, con dificultades, errores y aciertos. Los espańoles tuvieron que pasar por todo un periodo de tiempo, conocido como "La extirpación de idolatrías", cuando en el siglo XVII se dieron cuenta que la cristianización de los vencidos había sido un fracaso $^{7}$. Buena parte de este siglo estuvo dedicado a la

\footnotetext{
Francisco de Ávila, cura de la reducción de San Damián en Huarochirí, dio la voz de alerta de que los indios de su parroquia, habían introducido sus ídolos a la iglesia y que simulaban haber sido cristianizados. A partir
} 
política eclesiástica de extirpación de idolatrías, es decir, persecución, destrucción y represión generalizada a los símbolos de la religión prehispánica y de la continuidad de sus prácticas, tal como han sido tratados por Lorenzo Huertas (1981), Pierre Duviols (2003), entre otros.

Para los peninsulares, la conversión de los indígenas al cristianismo, no sólo fue un objetivo religioso, profundamente arraigada en casi toda Europa de la época, en constante lucha contra la propagación del Islamismo y de la reforma, encabezados por Martín Lutero y Juan Calvino, era toda una política de humanización y civilización de un mundo nuevo recién conquistado. La civilización era entendida como un proceso de integración de los vencidos hacia el modo de vida europeo. Eso significaba haber abrazado el cristianismo en primer lugar y luego vivir dentro del modelo de vida de los españoles, pero en situación de dominación. Ingresar al universo cristiano civilizado, significaba en primer lugar ser bautizado en la iglesia por el sacerdote católico. Luego cumplir con todos los sacramentos y encuadrar la vida cotidiana al modo cristiano, es decir, no sólo creer en los preceptos cristianos sino también modelar la vida en acatamiento de lo que significa ser buen cristiano, tema explicado con lucidez por Fernando Armas (2009). En este sentido, pasar de la barbarie o del salvajismo al modo cristiano de vida, fue entendido como un enorme tránsito de conversión hacia un nuevo universo, el civilizado y cristiano. Por esa razón, el cristianismo no sólo era la religión, verdadera y dominante, traída por los españoles, estaba atado a toda una estructura de pensamiento occidental, que abarcaba la cultura en general y al concepto de la civilización, también insertado a la religión cristiana católica. Toda la infraestructura monumental construida, las jerarquías religiosas implementadas y las múltiples normas que direccionaron los reyes, papas, concilios, obispados y catequizadores, tuvo por objeto civilizar a los indígenas de este nuevo mundo, a través de la cristianización.

\section{Puesta en valor del pasado colonial}

Principal objetivo de la remodelación de las iglesias coloniales en la zona andina es poner en valor las artes

de este hecho, el Arzobispado de Lima inició la represiva campańa de "extirpación de idolatrías". que atesoran estos edificios religiosos y fomentar el desarrollo económico y social, incrementando el turismo regional, que es una de las nuevas fuentes de ingreso para las poblaciones del interior del país, caracterizado por la pobreza. Sigue en importancia el proceso de neoevangelización de las nuevas generaciones de las provincias, en un momento de crisis, en torno a la fe religiosa católica, por el avance de los múltiples grupos del protestantismo en todo el país. En atención a uno u otro objetivo que viene ocurriendo en las últimas décadas, se observa como una de sus respuestas, el proceso de rescate del glorioso pasado de las iglesias andinas. No se trata de una política global para restituir todas las iglesias en mal estado en todo el país, que son muchas y tienen alto costo, es más bien una política orientada en la puesta en valor de las iglesias emblemáticas situadas en distintas regiones del país. Sobre este proceso, nos vamos ocupar, los casos de remodelación de iglesias en dos regiones del Perú: Ancash y Arequipa.

\section{a. Reconstrucción de iglesias en Ancash}

Las antiguas iglesias de la región Ancash fueron edificadas durante la época colonial, la mayoría de ellas en los siglos XVII y XVIII. Se construyeron como parte del proceso de cristianización de los indígenas, que comienza inmediatamente después de la conquista, pero se multiplicaron después de la creación de las reducciones de indios ordenadas por el virrey Toledo y de la aplicación de la política arzobispal de "extirpación de idolatrías", dirigidas desde Lima por los Arzobispos ${ }^{8}$. Fueron las órdenes religiosas las que se encargaron de la evangelización en todo el ámbito de la colonia. Dominicos, franciscanos, agustinos, mercedarios, jesuitas y otras órdenes venidas de España se ocuparon de cambiar las mentalidades de los vencidos hacia el cristianismo (Armas 2009; León 2009; Marzal 1983; Vargas Ugarte 1959). Con esta finalidad, se erigieron iglesias en todas las plazas principales de los pueblos fundados por ellos y en las reducciones de las zonas rurales. Se erigieron iglesias rurales, adecuadas para el tamaño de cada localidad, flanqueadas por una o dos torres para el campanario. Ocuparon un amplio espacio, en general una o media cuadra, que además incluía el cementerio en los costados del edificio religioso. El material uti-

8 Las campañas de extirpación de idolatrías comenzaron con el Arzobispo Bartolomé Lobo Guerrero (1607-1622) y continuaron con Gonzalo de Ocampo (1623-1626), Hernando Arias de Ugarte (1630-1638), y Pedro de Villagómez (1640-1671). 
lizado para su estructura fue principalmente el adobe y la piedra; la madera para los terrados del techo; se techaron con teja a dos aguas, pero en varias regiones el techo era de paja natural (ichu) de la puna. En esta zona del centro-norte, la iglesia de Mangas ${ }^{9}$ se ha mantenido techada de paja hasta el siglo XX; se cambió la paja por calamina en 1968 .

La mayoría de las iglesias andinas se hicieron con interiores de amplia nave, el altar, baptisterio, el coro y ambientes para la sacristía y almacén de utensilios. $\mathrm{El}$ altar y las paredes laterales de sus interiores fueron muy bien adornados con obras artísticas; los púlpitos y hornacinas de madera fina, enchapados en pan de oro y con abundante santería traída de España o hecha en el Perú. Algunas iglesias como las de Huanri en Ocros y Rapaz en Oyón, tienen pinturas religiosas a colores en sus paredes interiores, tal como han sido descritos por el arqueólogo Arturo Ruiz (1981). En algunas iglesias, el cielo raso de la nave estaba pintada de azul, con estrellas y luna, simulando el firmamento, como el que tenía la antigua iglesia de Santiago de Chilcas. Asimismo, la mayoría de las iglesias andinas tenían un órgano a fuelle, que se tocaba durante las misas. En la actualidad, los órganos coloniales ya no funcionan. Las excepciones conocidas son los órganos de Andahuaylillas en Cusco y de Yanque en el valle del Colca, en Arequipa. En general, las iglesias rurales son sencillas exteriormente, pero las obras de arte colonial se expresan en sus interiores. Sin embargo, algunas iglesias de esta región tienen hasta hoy hermosos frontales con obras escultóricas y pictóricas. Dos ejemplos son dignos de mención: el retablo exterior de la iglesia Santo Domingo de Huasta, en Bolognesi, que el sismo de 1970 no lo afectó mucho y también el retablo de la iglesia de Santo Domingo de Guzmán de Ocros, que sí se destruyó completamente.

El departamento de Ancash, situado en el centronorte del país, sufrió el 1970, un terremoto de 7.9 grados de intensidad en la escala de Richter. En este violento fenómeno telúrico perdieron la vida más de 70,000 mil personas, cientos de poblaciones quedaron en escombros y quedó devastado buena parte de la geografía de la zona, con destrucción de caminos, puentes, canales de riego, a lo largo y ancho de Ancash y provincias limítrofes. Uno de sus terribles efectos fue el aluvión del valle de Yungay, por el desprendimiento

9 Desde la época colonial, la renovación de paja de las diez y seis secciones del techo de la iglesia de Mangas se realizaba con una fiesta tradicional, con el baile de Mashas y Lumsuyes, que prevaleció hasta los años 60 . de la parte occidental de los nevados del Huascarán, sepultando al 90\% del pueblo de Yungay, una de las localidades más hermosas paisajísticamente de la región, por estar situado debajo del pico más alto de la Cordillera de los Andes del Perú. En general, el fenómeno telúrico del 31 de mayo dejó en escombros a poblaciones enteras del departamento. Muchas de ellas tuvieron que ser reubicadas en lugares más seguros, pero la mayoría prefirió quedarse en el mismo lugar, reconstruyendo sus viviendas con la ayuda de las instituciones del Estado que se crearon con esta finalidad.

Por sus efectos, el terremoto de 1970 provocó mucha destrucción en esta parte del país. Viviendas, edificios públicos, iglesias, quedaron en escombros, con excepción de algunas localidades que fueron afectados sólo parcialmente. En el emblemático valle, conocido también como Callejón de Huaylas, la iglesia matriz de Huaraz fue afectada totalmente. Otras iglesias, como la de Recuay, Carhuaz, Caraz y Huaylas, fueron igualmente destruidas total y parcialmente. En la misma medida, la mayoría de las iglesias del valle de los Conchucos, se vinieron al suelo, por la violencia del sismo. También por el lado sur de Ancash, la mayoría de las iglesias sufrieron las mismas consecuencias del terremoto. Las iglesias matrices de las principales poblaciones, de Chiquián y de Ocros, quedaron destruidas, como lo fueron también las iglesias de más de treinta localidades menores. Se salvaron algunas de ellas, como las de Huasta, Aquia, Acas, Pimachi, Huanri, Mangas, cuyas estructuras fueron afectadas parcialmente, en los techos y los campanarios. Lo interesante de esta tragedia natural, es que, las celebraciones festivas en homenaje a los santos patronos continuaron a pesar de la destrucción de estas iglesias coloniales.

Reconstruir las iglesias colapsadas y refaccionar las que fueron afectadas parcialmente ha tomado mucho tiempo y esfuerzo. Cuarenta y cinco años después del terremoto de 1970, se han restituido las iglesias de Ancash en casi $90 \%$. Un buen ejemplo es la iglesia matriz de San Sebastián de Huaraz, conocida originalmente como catedral, edificada a finales del siglo XVI, cuya reconstrucción está prácticamente concluida, con excepción de algunos detalles y acabados en su estructura general y en su moderno campanario. El trabajo de reconstrucción ha sido lento y costoso, bajo la conducción de la diócesis del Obispado de Huaraz. Para tal efecto se han formado, desde los años ochenta, varios comités de reconstrucción, conformado por personalidades del lugar y grupo de damas, que se han encargado 


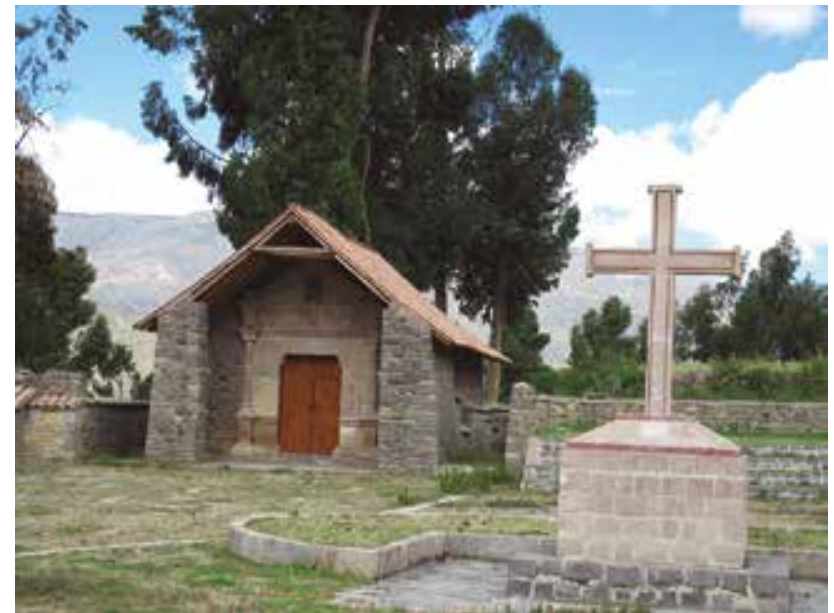

Figura 1. Cruz y capilla en el patio de la iglesia Santiago Apóstol de Coporaque, Arequipa.

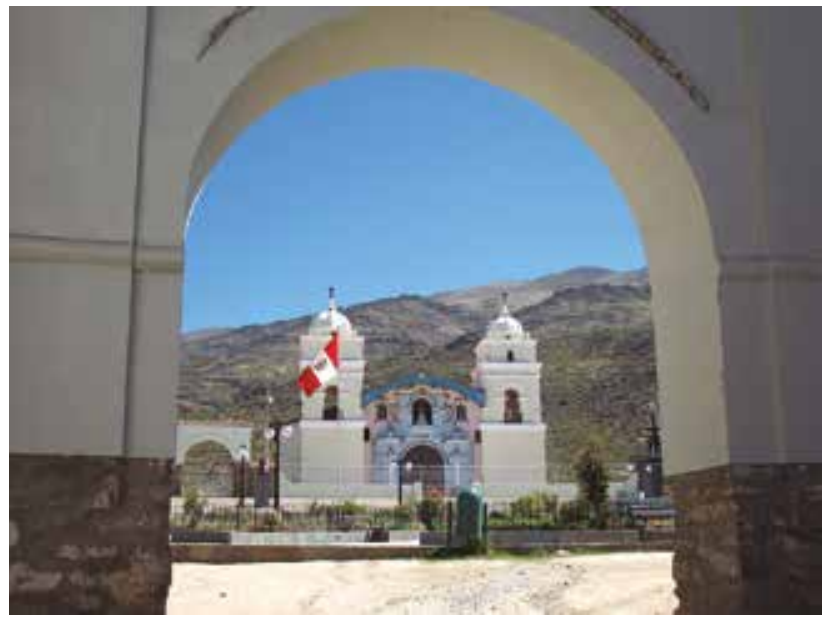

Figura 3. Vista panorámica de la iglesia colonial de Huamantanga, Canta.

de recolectar fondos pro templo. Con la cooperación de instituciones benéficas, nacionales y extranjeras, el apoyo económico del Gobierno Regional de Ancash y de las empresas mineras de Antamina y de la Barrick de Pierina, se está logrando concluir con la reconstrucción de lo que será la nueva catedral de Huaraz, situada en la plaza de armas. Como consecuencia de terremoto, se trasladó la sede de la catedral matriz a la iglesia de La Soledad, uno de los barrios de la ciudad, también refaccionada después del sismo. Hoy, la sede de la catedral ha vuelto a la plaza de armas, con la advocación de San Sebastián y de la virgen Inmaculada Concepción. Desde el siglo XVII, Huaraz ha estado dividido en cuatro barrios. Cada barrio mandó erigir su propia iglesia: San Francisco, Belén, La Soledad y la matriz, descritos muy bien por el historiador huaracino Francisco Gonzales (1992). Por más de tres décadas, los actos litúr-

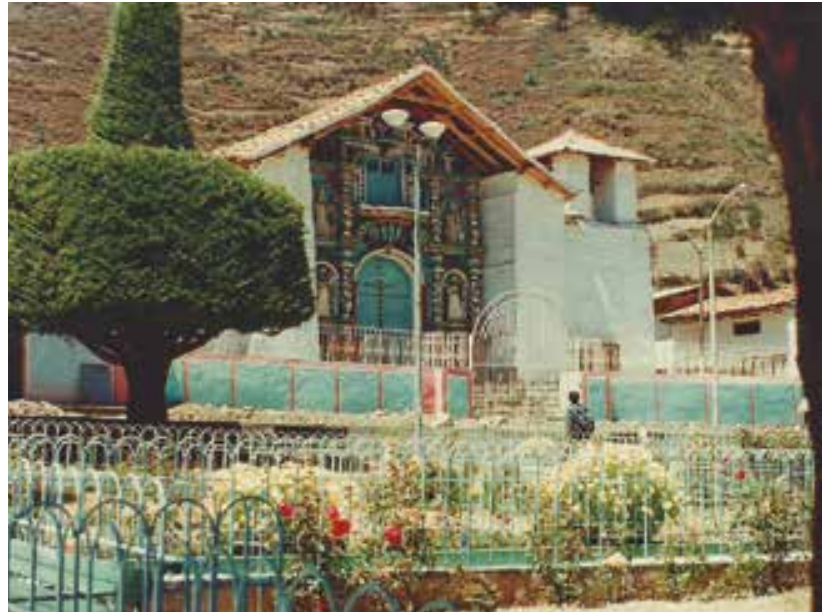

Figura 2. Retablo exterior de la iglesia Santo Domingo de Huasta, Ancash.

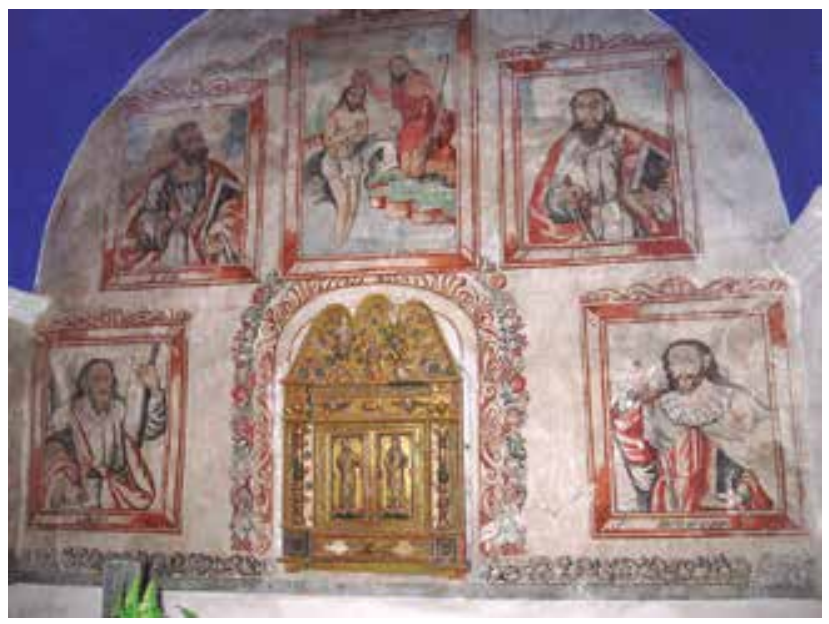

Figura 4. Pintura mural en la sacristía de la iglesia de Chivay, Arequipa.

gicos de la ciudad capital se han realizado en el barrio popular de La Soledad, más conocido por la imagen y la festividad del Señor de la Soledad. Otras iglesias de este valle han sido igualmente reconstruidas o refaccionadas por el esfuerzo de las mismas poblaciones, a través de comités pro templo, en la que han tenido destacada participación la diócesis de Huaraz, diversas instituciones y la oportuna cooperación de las familias migrantes a Lima y al extranjero.

Estas mismas acciones se han tenido que aplicar para reconstruir las iglesias del lado sur de Ancash, actuales provincias de Bolognesi y Ocros, con sus capitales Chiquián y Ocros. Con el terremoto de 1970 quedaron en escombros varias iglesias: San Francisco de Asis de Chiquián, San Bartolomé de Pacllón, San Pedro de Ticllos, San Agustín de Cajacay, Virgen del Carmen de Llipa, Virgen de la Natividad de Cajamar- 
quilla, Santiago de Chilcas, Santo Domingo de Guzmán de Ocros, Virgen del Carmen de Huanchay, San Pedro de Copa, entre otros. Reconstruirlas ha supuesto mucho tiempo y sacrificios. Ha merecido rápida reconstrucción la iglesia de San Francisco de Chiquián, que en los primeros años de la década del ochenta ya había sido reconstruida la iglesia y su campanario. Se vio favorecida por la presencia de un párroco europeo, el padre Finck, que contribuyó en organizar a la gente y a buscar fondos entre instituciones benéficas y personalidades chiquianas que se han forjado una solvente economía en Lima y otras ciudades de la costa. Tuvo especial participación en esta empresa de reconstrucción, la familia Bracale Ramos, afincada en Lima, que se encargó de financiar los costos fundamentales de la obra, además de otros hijos del pueblo chiquiano. Desde entonces, las fiestas tradicionales de Santa Rosa de Lima y de San Francisco de Asis, se realizan con todos los ingredientes de la tradición regional: los solemnes actos religiosos y las muchas actividades sociales y económicas que concurren a esta festividad.

También la iglesia de Ocros ha sido reconstruida, pero más lentamente. Con la cooperación económica de diversas instituciones, del Gobierno Regional de Ancash y de los hijos ocrosinos migrantes a Lima y al extranjero, culminó la reconstrucción del edificio y del campanario en el 2012. Hoy luce su prestancia, junto con otros edificios nuevos de la parte céntrica de la ciudad: la Municipalidad, el Juzgado de Primera Instancia, edificios particulares. Otras iglesias, como las de Pacllón, Cajacay, Corpanqui, Chilcas, ya han sido también remodeladas y están en pleno funcionamiento desde hace algunos años. Principalmente, la estructura del templo y de sus campanarios ya fueron terminados, pero los acabados interiores están siendo complementados en estos últimos años. Gracias a los esfuerzos sociales de reconstrucción de las iglesias de Ancash, hoy se les puede ver en sus nuevas estructuras de material noble. Un detalle especial, la nueva iglesia San Pedro de Ticllos ha culminado su reconstrucción moderna, con la dirección de un sacerdote italiano conocido, el padre Andrea Torresán, que se dedica no sólo a administrar la fe cristiana, sino a organizar y dirigir una empresa productiva con los comuneros del lugar. Hacen carpintería y ebanistería para la localidad y para la región; también se dedican a la agricultura y la ganadería mejorada en Ticllos y Roca. El padre Andrea es un sacerdote creativo en Ticllos, como lo es el industrioso padre Ugo de Censi, también italiano, quien ha fomentado el de- sarrollo social y económico, especialmente con el tallado en madera de puertas, ventanas y balcones, en la localidad de Chacas, provincia de Asunción, y ha participado en la reconstrucción y embellecimiento de varias iglesias siniestradas por el sismo en la provincia, incluyendo a la famosa iglesia de cúpulas de Pumallucay, situado en un lugar apartado del_Callejón de los Conchucos. Asimismo, la iglesia típica de una sola torre techada de tejas de Poquián, parte norte de la provincia de Cajatambo, cerca de Mangas, no resistió el movimiento telúrico del setenta, se vino abajo. Allí se ha construido una nueva iglesia, mucho más modesta, en la nueva población reubicada como consecuencia del sismo.

\section{b. Remodelación de las iglesias coloniales del Valle de Colca}

Colca es un valle interandino del departamento de Arequipa. Forma parte de la provincia de Caylloma, situada en la región sierra de Arequipa, distante en $160 \mathrm{Km}$ de la ciudad del Misti, cuya capital es Chivay. En este valle que se prolonga de este a oeste en $140 \mathrm{~km}$, existen 16 poblaciones, desde la formación de las "reducciones de indios" en el siglo XVI. En tiempos de los incas, el valle estaba habitado por dos grupos étnicos diferenciados: los collaguas que ocupaban la parte este y los cabanas asentados en el lado oeste. Fueron conquistados por el Inca Mayta Cápac ${ }^{10}$ y organizados en ayllus de pachaca. Los espańoles encontraron muchos grupos dispersos y los juntaron en las conocidas reducciones. Desde entonces cada localidad está organizada en comunidad campesina, que controla un espacio territorial definido, que sigue siendo usado para la agricultura y el pastoreo de ganado, según las tradiciones de data antigua. El valle de Colca, es además un destino turístico, que se promueve desde la ciudad de Arequipa, por su especial belleza paisajística de carácter natural y cultural. Allí está el cañón más profundo del territorio peruano $(4,150 \mathrm{~m})$, coronado por dos emblemáticas montańas nevadas, el Mismi $(5,597 \mathrm{msnm})$ por el lado noreste y el Hualca Hualca $(6,025 \mathrm{msnm})$ por el lado oeste. Su paisaje cultural está dibujado con extraordinarias andenerías prehispánicas, que están muy bien

10 Para fortalecer la alianza política con los collaguas, Mayta Cápac desposó con la ñusta Mama Tancaray-Yacchi, hija del curaca de Coporaque. El Inca cusqueño mandó construir un aposento cubierto de oro y plata, dedicado a su nueva consorte en seńal de reciprocidad y estima., cuyas ruinas todavía quedan en pie, junto a un moderno hotel turístico construido en los últimos años. 
cultivadas hasta nuestros días. El valle es también morada de cóndores andinos (Vultur gryphus) que anidan en los acantilados, cerca de Cabanaconde, que salen planeando por las mańanas, para el deleite de los turistas que aguardan en el mirador, desde el amanecer.

Durante la dominación colonial, se edificaron magníficas iglesias en cada localidad del valle. La iglesia fue parte del ordenamiento urbano de cada reducción. En la plaza central se ubicaron los espacios para la casa del curaca, del cabildo y de la iglesia, de acuerdo a la tradición española. A su vez, las iglesias pueblerinas recibieron la advocación de un santo que se constituyó en el patrono de cada localidad y se agregaron otros santos de acuerdo a los deseos de los doctrineros de cada reducción. Esas iglesias edificadas en los siglos XVI y XVII, prevalecen hasta hoy (Tord 1983; Ráez 2002). Son los expresivos testimonios del proceso de evangelización aplicado en esta región por los sacerdotes de la orden religiosa de los franciscanos, que participaron también en organizar las reducciones toledanas y a la catequización de indios de todo el valle. Buena parte de las iglesias construidas en esas poblaciones las dirigieron los franciscanos, con el apoyo de la administración colonial y de los encomenderos de la zona (Pease 1977; Tord 1983). El material utilizado para la construcción de las iglesias es, -parcialmente en algunos casos y en otras en todo el edificio- la piedra sillar, traída de las grabas volcánicas de la región. Estas piedras han sido modeladas en bloques similares a los adobes, unidos por argamasas de barro y yeso batido, para darle consistencia. Por el color blanco de los sillares, las iglesias de este valle son vistosas, que reflejan sus siluetas a larga distancia.

En todas las localidades del valle se han edificado iglesias con sus respectivas advocaciones fijadas desde la colonia, en el siguiente orden: San Pedro apóstol de Tisco, San Juan Bautista de Sibayo, San Antonio de Padua de Callali, Santa Cruz de Tuti, Nuestra Señora de Asunción de Chivay, Inmaculada Concepción de Yanque, Apóstol Santiago de Coporaque, San Juan Bautista de Ichupampa, Purísima Concepción de Lari, Santiago Apóstol de Madrigal, los Santos Reyes de Achoma, Santa Ana de Maca, San Sebastián de Pinchollo, San Pedro Alcántara de Cabanaconde, Virgen de la Candelaria de Tapay, San Lorenzo de Huambo. De todas ellas, la iglesia de Coporaque es la más antigua, por haber sido erigida en 1569. Allí establecieron los franciscanos su primera sede de evangelización. Otras iglesias, como la de Yanque, se edificaron a finales del siglo XVI, pero la mayoría se edificó en el siglo XVII. El diseño del arte arquitectónico utilizado es el rectángulo, con espacios adicionales a la nave central, el de Lari es en forma de cruz, con una cúpula en el cruce. La mayoría tiene dos campanarios situados en ambos lados del edificio, con excepción de las de Tuti, Achoma, Pinchollo, Madrigal y Tapay, que tienen una sola torre. Todas son iglesias de gran belleza, fundamentalmente por su parafernalia interior. Son consideradas como obras del "barroco mestizo" o barroco andino, por sus magníficos tallados de los altares, retablos, púlpitos y santerías. Algunas iglesias como la de Chivay, de Lari y de Maca, atesoran además pinturas murales en las paredes laterales y en las sacristías. Asimismo, habían en varias iglesias cuadros pintados en lienzo por artistas de la Escuela Cusqueña, de los que quedan muy pocos. Por información de los mismos pobladores sabemos que estas joyas pictóricas y objetos religiosos de plata (Cáliz, candelabros, coronas de vírgenes, etc.) han sido robados por gente inescrupulosa. El saqueo de los tesoros de las iglesias del valle de Colca y de casi todas las iglesias andinas del Perú, ha empobrecido a estos monumentos coloniales, por la desaparición de la inmensa riqueza artística depositada en estos recintos sagrados.

Con el paso del tiempo, las iglesias de sillar del valle de Colca se han deteriorado. A pesar de que todas las iglesias han pasado por refacciones en distintas épocas, el deterioro del patrimonio monumental de esta región ha sido afectado por distintas causas en los más de cuatro siglos de existencia. Esta región de Arequipa, rodeada de volcanes y altas montañas nevadas, ha sido siempre una región sísmica. Hay allí varios volcanes inactivos, que erupcionan sorpresivamente, causando pánico en las poblaciones y afectando a la geografía y a las frágiles edificaciones humanas. Uno de los volcanes que se ha activado varias veces en el siglo XX es el Sabancaya. Hace apenas tres años mostró su violencia telúrica $(2,013)$ cubriendo de cenizas a buena parte de las poblaciones del lado oeste, dejando varias víctimas humanas, además de provocar destrucción en las viviendas. Un reciente sismo de 5.3 grados de intensidad en la escala de Richter (15/07/16) ha dejado en escombros a varias localidades de ambos lados del río Colca, tales como Ichupampa, Yanque y Achoma, dejando además varias víctimas mortales. La onda expansiva del fenómeno telúrico alcanzó a otros pueblos cercanos a los indicados, como Lari, Coporaque y Madrigal, en la margen derecha, Maca, Cabanaconde y Chivay 
en la margen izquierda. La historia de estos pueblos del sur peruano está matizada con frecuentes sismos de distinta intensidad, que se presentan con intervalos impredecibles. Le siguen a estos fenómenos naturales, la intensidad de las lluvias, los ventarrones, la humedad y el descuido de las poblaciones por mantener las iglesias en buen estado. Todos estos factores han afectado lentamente a estas iglesias coloniales, por lo que han requerido permanente mantenimiento y reparaciones. Otro factor ha sido también el poco uso de las iglesias, por el abandono de la diócesis de Arequipa, de no proveer de sacerdotes a las principales iglesias. Sólo en Chivay se ha mantenido permanentemente el servicio religioso con sacerdotes estables, que además ha prestado servicios en todo el valle. Por estas causas, las actividades religiosas, se circunscriben fundamentalmente a las fiestas patronales que se festejan en cada localidad. Son en esos días que las iglesias abren sus puertas a la feligresía, pero casi todo el año están cerradas, con excepción de la capital de la provincia, en las que se ofician misas todos los domingos. Por estas y otras causas, todas las iglesias del valle de Colca se encontraban hasta finales del siglo anterior, en mal estado de conservación, tanto en sus estructuras como en sus reliquias interiores.

Este problema encontró la solución esperada, cuando en 1997 se concretó el apoyo internacional para restaurar las diez y seis iglesias del valle de Colca. Ese año inició sus operaciones, la Agencia Espańola de Cooperación Internacional para el Desarrollo (AECID). Esta agencia, dependiente del Ministerio de Asuntos Exteriores de España, que a través de su Secretaría de Estado para la Cooperación Internacional y para Iberoamérica, se encarga de ejecutar diversos programas de restauración de monumentos históricos en diversos países de América y otros continentes donde han tenido presencia histórica, con el objetivo de poner en valor las joyas arquitectónicas, pinturas y esculturas coloniales, que se encuentran en mal estado de conservación. Uno de sus primeros logros en el Perú ha sido la restauración del antiguo Convictorio de San Carlos de Lima, hoy conocido como Centro Cultural de la Universidad Nacional Mayor de San Marcos. Para el caso de las iglesias del valle de Colca, la Agencia envío un equipo de especialistas en el arte de restauraciones, bajo la responsabilidad de un ejecutivo nombrado. Con este fin, la cooperación española ha aportado un fondo de $\$ 3^{\prime} 500,000$ dólares americanos para las obras de restauración, mientras que los muni- cipios de la parte peruana han destinado el $20 \%$ del total de los gastos presupuestados. Asimismo, el Gobierno Regional de Arequipa y la Autoridad Autónoma del Colca (Autocolca) han contribuido con fondos adicionales para continuar con las obras de restauración desde el 2010 para adelante. Con la financiación asegurada y la acción de restauradores especializados y campesinos adiestrados, ha sido posible poner en valor estas magníficas iglesias coloniales del Colca en la sierra de Arequipa.

La ejecución del proceso de restauración de las iglesias se ha desarrollado por etapas. Lo primeo que hizo el equipo de restauración fue el inventario y evaluación de las iglesias del valle, con la descripción del estado en que se encontraban. Instalados en Chivay, capital de la provincia de Caylloma, dedicaron el tiempo necesario para organizar talleres de sensibilización e incentivación de las poblaciones, para valorar sus bienes monumentales, seleccionar jóvenes, varones y mujeres, para adiestrarlos en el arte de restauraciones de paredes, tallados de madera, reparación de lienzos, de murales y reparación y retocado de las imágenes de santos. Con el apoyo de este grupo de restauradores de las mismas poblaciones del valle, los técnicos españoles iniciaron la tarea de restauración de iglesias. Dos iglesias consideradas como las que guardan las mejores joyas artísticas en sus estructuras y en la magnífica implementación de sus interiores, fueron escogidas para emprender el objetivo de la restauración: la iglesia Purísima Concepción de Lari y la iglesia Santa Ana de Maca. En ambas iglesias han trabajado simultáneamente, en el saneamiento de las estructuras (Paredes, techos, campanarios, contrafuertes); limpieza general de sus interiores; la reparación de los altares, retablos, púlpitos, coros; saneamiento y curación de las esculturas de Cristos, santos y santas, así como de la iluminación de los interiores y exteriores de las iglesias. En ambas iglesias han trabajado grupos distintos de restauradores nativos, bajo la directa administración de los especialistas españoles. Paralelo a las obras de restauración, se organizaron talleres en las dos sedes, con el propósito de adiestrar a nuevos jóvenes interesados en el arte de curación y restauración, perfeccionar a los adelantados y sensibilizar a la población para reforzar sus identidades culturales con los templos coloniales (Gutiérrez 2003).

Todo este proceso se puso en marcha desde el año 1998 y ha continuado ininterrumpidamente durante los diez primeros ańos, en su primera etapa. Cuando 
los trabajos de restauración en Lari y Maca fueron avanzando con éxito, se iniciaron los trabajos en las otras iglesias, como en las de Nuestra Seńora de la Asunción de Chivay, Inmaculada Concepción de Yanque y Santiago Apóstol de Coporaque. Estas cinco principales iglesias del valle están ya concluidas en sus reparaciones generales. Los visitantes nacionales y extranjeros que llegan a estos lugares pueden admirar ahora la belleza externa e interna de estos edificios sagrados, con la magnificencia del pasado colonial, con sus altares, retablos, hornacinas y púlpitos bien pintadas en pan de oro y en sus colores originales. La fachada y la estructura de todo el complejo monumental, debidamente reforzadas, reparadas y pintadas. La iluminación natural por la remoción de los ventanales y claraboyas, ha sido mejorada con la iluminación eléctrica, adecuada a cada edificio. En el frontis y en los laterales de estas iglesias se han colocado reflectores eléctricos, que durante las noches iluminan la majestad de estas construcciones coloniales. Un efecto inmediato de la remodelación de las iglesias del valle es la mayor concurrencia de los turistas que llegan al valle y gran concentración de feligreses durante los rituales de las fiestas patronales. Por su puesta en valor, los habitantes de estas localidades, sienten ahora orgullo por sus monumentos, lo consideran suyos, por haber sido rescatados del olvido centenario, el desinterés, el deterioro permanente y el saqueo sacrílego de sus tesoros perpetrado por gente de dentro y de fuera.

El siguiente paso ha sido ampliar la remodelación hacia todas las demás iglesias, según los avances en el adiestramiento de curadores y restauradores de las mismas poblaciones. En distintos momentos, con la dirección de los especialistas espańoles, se iniciaron y avanzaron los trabajos en las iglesias de: Santiago de Madrigal, San Pedro Alcántara de Cabanaconde, San Sebastián de Pinchollo, San Juan Bautista de Ichupampa, Santa Cruz de Tuti, San Pedro Apóstol de Tisco, San Antonio de Padua de Callali, Virgen de la Candelaria de Tapay y San Lorenzo de Huambo. Desde el ańo 2009, los procesos de restauración de monumentos, ha contado con nuevos presupuestos, arriba citados. Una parte de los fondos ha provenido del boletaje turístico al valle de Colca, controlado por Autocolca, institución creada para el desarrollo turístico en la región. Con estos aportes, continúan los trabajos de restauración de las iglesias en sus distintos aspectos, que el apoyo directo de AECID no logró concluir en su totalidad. Lo importante es que en esta etapa, son los mismos lugareños, muy bien especializados por los técnicos españoles, los que han asumido la responsabilidad de las restauraciones artísticas, con el apoyo técnico necesario. Esto quiere decir, que ellos mismos han aprendido el arte de restauraciones monumentales y a darle valor a sus recursos culturales. Desgraciadamente, el último sismo del mes de agosto ha afectado a la estructura y a las imágenes de buena parte de las iglesias recién restauradas.

\section{Nuevo esplendor de las iglesias y de las tradiciones}

En ambos espacios estudiados, las iglesias fueron edificadas cuando en Europa se vivía el movimiento postrenacentista, seguido por el barroco en las expresiones artísticas. Al trasladar estos conocimientos hacia este continente recién conquistado, se aplicaron principalmente esos modelos europeos, combinados con percepciones estéticas americanas. A esta fusión de estilos se le ha llamado "barroco mestizo" o "barroco indígena”. Autores como Norma Campos Vera y otros (2012) y Teresa Gisbert (1980) se han ocupado en estudiar y analizar este tipo de artes en los países de Iberoamérica, con abundante iconografía de por medio. En las principales ciudades como Quito, Lima, Ayacucho, Cusco, Arequipa, Puno, los templos mandados construir por las distintas órdenes religiosas, muestran con plenitud el barroquismo europeo; en las localidades menores del interior del país aparecen mejor el modelo mestizo, en sus estructuras, sus campanarios, sus pinturas murales y sus imágenes, donde aparecen los símbolos del sol, la luna, las estrellas, el cóndor, las sirenas y paisajes andinos, así como ángeles y todo tipo de imágenes sagradas del cristianismo. Los arquitectos españoles no escatimaron en aplicar los modelos europeos en boga en las estructuras de los templos y en la riqueza de los aditamentos de sus interiores. Esos estilos arquitectónicos se aplicaron también en los retablos exteriores de templos, como el de Ocros, de Chiquián, de Pacllón, que el terremoto del 70 dejó en escombros, pero otros quedaron en pie, como los magníficos retablos de la iglesia de Huasta y de Aquia, ahora mejor conservados que en el pasado. Las iglesias del valle de Colca, no destacan tanto por sus retablos exteriores, destacan por sus estructuras reforzadas con varios contrafuertes y el material volcánico del sillar. Brillan por sus altares, púlpitos y retablos interiores, donde las artes neoclá- 
sicas le agregan inestimable valor. Una muestra de la exquisitez del arte barroco en la pintura, la escultura y la arquitectura, es la iglesia Purísima Concepción de Lari, considerada como "la catedral del Colca", situada en la margen derecha del río Colca, hoy totalmente remodelada. También es un buen ejemplo, la robusta iglesia franciscana de Coporaque, de sólidos contrafuertes exteriores, de sus edificaciones conventuales y su magnífica plaza de catequización colectiva, con una cruz en el centro, una capilla en un extremo y ambientes con arcadas en uno de sus laterales.

Sin duda, la política de restauración de los monumentos arquitectónicos dejados por la colonización española en América, está ligada a la dinamización de la evangelización moderna, al mismo tiempo que favorece al incremento del turismo, uno de los mecanismos del desarrollo económico que requieren las naciones de América Latina. El primer objetivo forma parte de la política ecuménica de ampliación y profundización de la fe cristiana, dirigido desde el papado de Roma y administrado por el Arzobispado de Lima y los Obispados de las regiones. Las actividades religiosas encaminadas a ese propósito, tuvieron mayor relevancia durante las peregrinaciones internacionales ${ }^{11}$ del Papa Juan Pablo II, que fue conocido como el "Papa peregrino". Por entonces, la Iglesia Cristiana se venía disgregando aun más, por la propagación de distintas formas del protestantismo y también por el avance de la religión islámica. Paralelo a las peregrinaciones, se impartieron directivas hacia todas las latitudes donde se profesa el cristianismo católico, para que las iglesias se conviertan en centros de avivamiento católico, a través de distintos mecanismos religiosos que se practican en la administración de los sacramentos. Por estos hechos, la neoevangelización que se practica en casi todas las iglesias peruanas de hoy, es la continuidad de las preocupaciones de Juan Pablo II, que los dos papas siguientes continúan alentando con vigor.

Para el caso peruano, los esfuerzos de la restauración de las iglesias coloniales, tiene mejor efecto en la promoción del turismo, al mismo tiempo que aporta en los propósitos de la neoevangelización rural. Tanto en la región de Ancash como en la de Arequipa, están presentes los dos objetivos básicos: incentivar la religio-

11 Juan Pablo II visitó dos veces al Perú, en febrero de 1985 y mayo de 1988. Además de Lima visitó varias ciudades del interior: Cusco, Arequipa, Ayacucho, Iquitos. En el Cusco coronó a la Virgen del Carmen de Paucartambo, en Arequipa a la Virgen de Chapi. En Iquitos fue declarado como el "Papa charapa". sidad en las iglesias remozadas en su belleza cercana a la original, también ofrecer a los turistas nacionales y extranjeros, nuevas experiencias con monumentos cabalmente restaurados por manos nativas y extranjeras. Cuarenta y cinco años después del terremoto de 1970 en Ancash, las iglesias restauradas lucen sus nuevos perfiles, que contrastan con los modelos arquitectónicos que dejaron los espańoles. Las del valle del Colca, que se han venido deteriorando desde el siglo XIX, hoy muestran su antiguo esplendor, en un medio rural con predominio de la actividad agrícola-ganadera, de inmenso potencial cultural prehispánico, colonial y republicano. Estas remodelaciones del arte colonial, se realizan en tiempos de grandes cambios en el mundo rural peruano. Principalmente desde comienzos de este siglo, pueblos y comunidades del interior del país están cambiando su fisonomía, en lo social, cultural y económico. Por esta nueva dinámica, la imagen tradicional de los pueblos del interior está dando paso al nuevo perfil de la modernidad del ámbito rural.

Por el proceso migratorio del campo a la ciudad, la profesionalización de jóvenes, el ingreso al mundo del comercio y a la pequeña y mediana industria de las nuevas generaciones de migrantes que se han trasladado a las ciudades y al extranjero, el retorno a la tierra natal o a la tierra de sus padres y abuelos, se realizan con muchos apoyos económicos. Esta nueva dinámica social acentúa los cambios en la estructura social y económica de las poblaciones. Las remesas de procedencia interna y externa que llegan a los pueblos andinos, constituyen otra forma de incremento de la economía familiar de muchas localidades, que contribuye a la modernización rural. Por otro lado, debido a la ampliación de las redes de carreteras, las familias campesinas han aprendido a cultivar y a criar, cada vez más, productos agrícolas y ganaderos, con destino al mercado regional, nacional y en algunas regiones para el mercado internacional. La vieja economía campesina de autoabastecimiento tiende a desaparecer, por orientarse hacia el mercado. Los pueblos del interior del país ya no están aislados como en el pasado. La movilidad social costa-sierra es ahora intensamente dinámica. Los "muros que separaban a la república de indios y la república de blancos" se han venido abajo, como el muro de Berlín. Por esta nueva dinámica social, la globalización alcanza también a los espacios del mundo rural del Perú.

A pesar de la crisis económica, las costumbres y tradiciones locales y regionales no se han debilitado, se mantienen firmes y tienden a masificarse, con sus 
nuevas manifestaciones musicales, dancísticas coreográficas; también por la afluencia del turismo interno, avivado por el flujo de "retornantes" de las ciudades y del exterior. Viejas costumbres como las "fiestas patronales", implementadas por los catequizadores españoles, han dado paso a fastuosas fiestas, donde fluyen visitantes diversos y confluyen todas las artes festivas en su versión moderna. Son esas manifestaciones populares masificadas, las que se observan en fiestas patronales, como las de la Mama Meche (Virgen de las Mercedes) de Carhuaz en el valle de Huaylas, de la Mama Huarina (Virgen del Rosario) de Huari en el valle de los Conchucos, de Santa Rosa de Lima en Chiquián, en la provincia de Bolognesi. Igualmente modernizadas y masificadas son las fiestas patronales del valle de Colca, principalmente la fiesta dedicada a la Virgen de la Inmaculada Concepción en Chivay, que se realizan con extraordinario despliegue de danzarines del wititi, muy populares en la región ${ }^{12}$, o la fiesta dedicada a la Virgen del Carmen en la localidad de Cabanaconde, con la presencia de grandes bandas de músicos contratadas de Puno y las bandas famosas de Madrigal, tierra de excelentes músicos en el valle. Bajo el fondo de las iglesias coloniales restauradas, donde se realizan las misas abarrotadas de feligreses y de donde salen las procesiones de las santas patronas, el sentido devocionario y festivo costumbrista de las poblaciones muestran su moderna expresión popular. Hay sobre este tema, interesantes estudios que ilustran bien la grandiosidad costumbrista de las festividades, como el de Martine du Authier (2009) dedicada a la fiesta de la Virgen del Carmen de Paucartambo en Cusco, el de Verónica Salles-Reese (2008) sobre la Virgen de Copacabana en Bolivia, el de Manuel Ráez (2002) para las festividades del valle de Colca, así como el interesante estudio multidisciplinario sobre fiestas en los países de América Latina liderada por Norma Campos Vera (2912), además de muchas publicaciones de libros y folletos sobre fiestas patronales en el Perú de nuestros tiempos. Dentro de todo este proceso de cambios sociales y culturales, se agrega con particular lucidez, la restauración de las iglesias andinas.

12 En las últimas tres décadas, tanto en las fiestas del valle de Colca como en las diversas regiones del Perú rural, son los migrantes a las ciudades de la costa peruana o los que viven en países del exterior (EE.UU, Japón, Italia, Argentina, etc.) los que asumen los cargos festivos, en sustitución de sus padres, actitud que viene dando mayor lustre a estas manifestaciones populares andinas de estos tiempos.

\section{Referencias bibliográficas}

Armas Asín, Fernando (Editor) (2009). La invención del catolicismo en América. Los procesos de evangelización, siglos XVI-XVIII. UNMSM, Lima, Perú.

Autiers, Martine du (2009). La fiesta andina: Mamacha Carmen en Paucartambo. Editorial San Marcos, Lima-Perú.

Campos Vera, Norma (Editora) (2012). Imagen del poder. Editorial Visión Cultural, La Paz, Bolivia.

Compañía de Jesús (2015). Ruta del barroco andino. Guía de visita. Compañía de Jesús Provincia del Perú - Asociación Sempa, Cusco (DVD).

Cuevas, Mariano (1947). Historia de la iglesia en México. Edit. Patria, México (5 vol.).

Dianich, S. (2013). La Iglesia y sus iglesias. Fondo Editorial de la PUCP, Lima, Perú. (Traducido del título original: La Chiesa e le sue Chiese, por el padre Carlos Castillo).

Duverger, Christian (1996). La conversión de los indios de Nueva España. FCE, México.

Duviols, Pierre (2003). Procesos y visitas de idolatrías. Cajatambo, siglo XVII. PUCP-IFEA, Lima, Perú.

Gisbert, Teresa (1980). Iconografía y mitos indigenas en el arte. Gisbert y Cia., La Paz, Bolivia.

Gonzales, Francisco (1992). Huarás: visión integral. Ediciones Safori, Huarás, Perú.

Gutiérrez, Ramón (2003). El valle de Colca, patrimonio es desarrollo. Ministerio de Asuntos Exteriores, Madrid.

Huertas Vallejos, Lorenzo (1981). La religión en una sociedad rural andina (Siglo XVII). Universidad Nacional San Cristóbal de Huamanga, Ayacucho, Perú.

León Fernández, Dino (2009). Evangelización y control social a la doctrina de Canta. Siglos XVI y XVII. Fondo Editorial, F. CC. SS., UNMSM, Lima.

MARZAL, Manuel M. (1983). La trasformación religiosa peruana. PUCP, Lima.

Ministerio de Asuntos Exteriores de España (2003). Evaluación del Programa de Patrimonio Cultural de la Cooperación Española. Secretaría de Estado para la Cooperación Internacional y para Iberoamérica, Madrid.

Raez Retamozo, Manuel (2002). En los dominios del cóndor. Fiestas y música tradicional en el valle de Colca. Centro de Etnomusicología andina, PUCP, Lima.

Robles Mendoza, Román (2005). "Las iglesias andinas: huellas de la cristianización y religiosidad popular", $R e$ vista de Antropología, No 3, UNMSM, Lima.

Robles Mendoza, Román (1978). "La religión cristiana en el proceso de colonización del mundo andino: destrucción y supervivencia de las prácticas religiosas prehispánicas en Mangas (Cajatambo-Bolognesi)”. En Koth de 
Paredes, María y Amelia Castelli (Comps.). Etnohistoria y antropología andina. Primera Jornada del Museo de Historia (1976), pp. 225-235, Lima.

Ruiz Estrada, Arturo (1981). "La iglesia de San Cristóbal de Rapaz, joya del arte mural andino". Suplemento de la Rev. Ahora, ciudad de Huacho, Perú.

Sahagún, Fray Bernardino de (1975). Historia general de las cosas de Nueva España, Ed. Porrúa, México.

Sahagún, Fray Bernardino de (1986 [1582]). Coloquios y doctrina cristiana con que los doce frailes de San Francisco enviados por el Papa Adriano VI y por el emperador Carlos $V$, convirtieron a los indios de Nueva España. En lengua mexicana y española. UNAM y Fundación de Investigaciones Sociales, México.
Salles-Reese, Verónica (2008). De Viracocha a la Virgen de Copacabana. IFEA - Plural Editores, La Paz, Bolivia.

SAn Cristóbal, Antonio (2004). Esplendor de la arquitectura colonial. Ed. Peisa, Lima.

Tord, Luis Enrique (1983). Templos coloniales del Colca, Arequipa. Lima.

Vidal Valladolid, Miguel Ángel (2013). La dimensión arquitectónica del ritual en las iglesias de Lima del siglo XX. UNI Editorial Universitaria, Lima, Perú.

Vargas Ugarte, Rubén (1953-1962). Historia de la iglesia en el Perú, Ed. Burgos, Lima (5 tomos).

Vargas Ugarte, Rubén (1951-1954). Los Concilios Limenses. Lima (3 tomos). 